\title{
1 Longtime behavior of cesium (Cs) in natural spring drinking
}

2 water

3 Shinji Nakaya ${ }^{\mathrm{a}}{ }^{*}$, Hoang Minh Ha Phan ${ }^{\mathrm{a}}$, Yoshiki Iwai ${ }^{\mathrm{a}}$, Akihiro Itoh ${ }^{\mathrm{a}}$, Hideto Aoki ${ }^{\mathrm{a}}$, Takanori

4 Nakano $^{\mathrm{b}}$

5

$6 \quad{ }^{a}$ Department of Civil Engineering, Shinshu University, 4-17-1, Wakasato, Nagano, Japan.

$7 \quad{ }^{\mathrm{b}}$ Research Institute for Humanity and Nature, Motoyama 457-4, Kita-ku, Kyoto-603-8047, Japan.

\section{$9 \quad$ ABSTRACT}

10 Large amounts of radioactive cesium $\left(\underline{\mathrm{Cs}^{\mathrm{A}}}\right)$ have been introduced into the underground 11 environments, through a natural process, as a result of nuclear power plant accidents. It is known

12 that the active Cs sorption onto colloidal-size clay minerals in groundwater is observed and the 13 active Cs can be transported with the colloidal fraction of groundwater by water flows. However,

14 the longtime behavior of radioactive $\mathrm{Cs}$, contained in the flowing groundwater in the aquifers of

15 groundwater source areas, is unknown in terms of the natural water cycle. Herein, we investigate

16 the Cs concentration in natural spring drinking water with the residence time in a groundwater

17 source area of a mountainside composed of volcanic rock, compared with those of other trace

18 elements. This investigation demonstrates that the observed Cs concentration in natural spring

19 drinking water exponentially decreases slowly with the groundwater residence time $(\sim 45 \mathrm{yr})$,

20 while several trace elements, namely, P, V, Ga, and Ge, increase in concentration with the

21 * Corresponding author. Tel.: +81 26269 5316; fax: +81 262695271

22 E-mail address: nakayas@shinshu-u.ac.jp (S. Nakaya). 
23 groundwater residence time through chemical weathering. The findings suggest that $\underline{\mathrm{Cs}^{\mathrm{A}}}$,

24 contained in flowing groundwater in mountain water source areas, may decrease exponentially

25 at the rate of one-tenth in twenty-two years, by sorption onto the aquifer through rock-water

26 interaction excluding radioactive decay. For the sustainable management of water sources and

27 ecosystems, the long-term ( $\sim 50$ yrs.) monitoring of the active Cs in groundwater is needed in

28 mountain water source areas where radioactive cesium has been dispersed at times of nuclear

29 power plant accidents.

31 Keywords:

32 Groundwater / Cesium / Sorption / Residence time / Sulfur hexafluoride / Nuclear power plant 33 accidents

$35 \quad$ 1. Introduction

36 The longtime ( $100 \mathrm{yr})$ effect of radioactive cesium $\left(\mathrm{Cs}^{\mathrm{A}}\right)$, dispersed at the time of nuclear 37 power plant accidents (e.g., von Gunten et al., 1988; Mizuno and Kubo, 2013; Tsuji et al., 2014),

38 is a major environmental issue. As $\mathrm{Cs}^{\mathrm{A}}$ is sorptive onto colloidal-size clay in groundwater 39 (Francis and Brinkley, 1976; Comans et al., 1991; Kersting et al., 1999) and the distribution 40 coefficient to the subsurface soil of $\mathrm{Cs}^{\mathrm{A}}$ decreases with depth in the soil (Comans et al., 1989), 41 the active Cs can be transported by water flows with the colloidal fraction, with suspended 42 particles of sub micrometer size (von Gunten et al., 1988; Buddemeier and Hunt, 1988; Kersting 43 et al., 1999; Tsuji et al., 2014), and can reach the groundwater surface (Kersting et al., 1999). 44 Although $\mathrm{Cs}^{\mathrm{A}}$ sorption onto soil has been reported (Francis and Brinkley, 1976; Comans et al., 
45 1991; Buddemeier and Hunt, 1988), the temporal variation in field groundwater $\mathrm{Cs}^{\mathrm{A}}$ by sorption 46 onto rock aquifers is still unknown in terms of the natural water cycle, and the longtime behavior $47 \quad(10-50 \mathrm{yr})$ of the $\mathrm{Cs}^{\mathrm{A}}$ concentration in groundwater has rarely been observed.

48 In order to evaluate the longtime behavior of $\mathrm{Cs}^{\mathrm{A}}$ in the flowing groundwater of an important 49 source area, this study focuses on the Cs in the spring water of the Yatsugatake Mountains, 50 which form an important source area for drinking water in Central Japan. In the Saku district, a 51 high land area, $650 \mathrm{~m} \sim 2,500 \mathrm{~m}$ in altitude, in the northeastern section of the Yatsugatake 52 Mountains in Nagano, Japan, $280 \mathrm{~km}$ southwest of the site of the Fukushima Daiichi Nuclear 53 Power Plant accident (Fig. 1), the groundwater, spring water, and well water in the volcanic rock 54 aquifer have been used for $99 \%, 47 \%$, and $52 \%$, respectively, of the drinking water and tap 55 water in that district for a long time. According to all the local Government HPs in the Saku 56 district, no $\mathrm{Cs}^{\mathrm{A}}$ was detected (detection limit $<0.1 \sim 10 \mathrm{~Bq} / \mathrm{kg}$ ) from the groundwater for the 57 water works, but $\mathrm{Cs}^{\mathrm{A}}$ was detected from the drainage sludge in certain areas. Spring water is still the major source of drinking and tap waters in high land areas of Japan. As the sorption and

59 desorption behavior of the Cs in groundwater should be equal to that of Cs ${ }^{\mathrm{A}}$ (e.g., Cornell, 1993;

60 Yoshida et al., 2004), the longtime behavior (10-50 yr) of the $\mathrm{Cs}^{\mathrm{A}}$ concentration in the 61 groundwater flowing through aquifers is expected to be obtainable by field monitoring the 62 relationship between the Cs concentration in groundwater and the residence time of the 63 groundwater in a rock aquifer that includes Cs-bearing minerals. In this study, the Cs 64 concentration in natural spring drinking water was measured with the groundwater residence 65 time, in order to evaluate the longtime behavior of $\mathrm{Cs}^{\mathrm{A}}$ in the flowing groundwater of an 66 important source area for drinking water in terms of the natural water cycle. 


\section{$68 \quad 2 . \quad$ Material and methods}

$69 \quad 2.1 \quad$ Sampling locations and geological setting of the study area

70 Sampling points are located in the northeastern part of the Yatsugatake volcanic area, which is 71 part of the Yatsugatake-Chūshin Kōgen Quasi-National Park. The Yatsugatake volcanic body, formed by Quaternary volcanic activity from 0.8 to $1.2 \mathrm{Ma}$, is comprised mainly of several thin

73 flows of pyroclastics, including volcanoclastic, basaltic lava, and basaltic andesitic lava (Nishiki 74 and Takahashi, 2012). The slopes are about 0.13 for higher than $1,600 \mathrm{~m}$ a.s.1., and about 0.08 for lower than 1,600 $\mathrm{m}$ a.s.l. and for higher than 1,000 $\mathrm{m}$ a.s.l. Most parts of the study area belong to the Yachiho Group of early Pleistocene, consisting of five formations. These formations are comprised mostly of volcanic sand and gravel with scoria and tuff breccia; namely, pyroclastics, including the volcanoclastic of Nishiki and Takahashi (2012), compose the aquifers of $30 \mathrm{~m}$ to $50 \mathrm{~m}$ in thickness (Kumai, 1980). After the Yachiho Group was uncomfortably covered and leveled by a gravel formation, the mountain ridges separated from one another due to the erosion of valleys in the geologic body (Kumai, 1980). Kumai (1980) also reported that each hydraulic parameter of the aquifers in the Yachiho Group ranged from $10^{-6}$ to $10^{-4} \mathrm{~m} / \mathrm{sec}$ in hydraulic conductivity and from 0.06 to 0.4 in effective porosity,

84 respectively.

85

$86 \quad 2.2 \quad$ Sampling and analysis of spring water

87 We collected groundwater samples from July to August 2011 from the 17 (cold) springs, $780 \mathrm{~m}$

88 to $1,940 \mathrm{~m}$ a. s. 1. in altitude (Table 1), that are being used for drinking and tap waters as supplied 
from the local government in the Saku district (Fig. 1). In addition, the water from 25 rivers, as

90 well as the 17 springs, was sampled for measuring the hydrogen and oxygen stable isotopic

91 ratios $\left(\delta \mathrm{D}\right.$ and $\left.\delta^{18} \mathrm{O}\right)$ to trace the origin and the recharge area of the water. The $\mathrm{pH}$, the electrical

92 conductivity (EC), the oxidation reduction potential (ORP), and the dissolved oxygen (DO) of

93 the groundwater samples were measured in the field using portable instruments (SC82,

94 Yokogawa Electric Co., Japan; D-25, Horiba, Ltd., Japan). The groundwater samples were

95 collected using a nylon tube, with each spring purged until the monitoring values for $\mathrm{EC}, \mathrm{pH}$,

96 DO, ORP, and temperature (T) became stable. Samples for the chemical composition were

97 collected in $50-\mathrm{mL}$ and $250-\mathrm{mL}$ polyethylene bottles filtered through a $0.2-\mu \mathrm{m}$ membrane filter.

98 The groundwater samples for the sulfur hexafluoride $\left(\mathrm{SF}_{6}\right)$ and chlorofluorocarbons (CFCs:

99 CFC-12 and CFC-113) dating were collected unfiltered and without exposure to the air in 1-L

100 glass bottles for $\mathrm{SF}_{6}$ and in 100-mL glass bottles for CFCs, as described by Busenberg et al.

101 (2006) in the IAEA (International Atomic Energy Agency) guidebook. $\underline{S F}_{6}$ and CFCs were

102 measured separately by purge-and-trap gas chromatography systems, namely, Shimadzu GC-8A

103 and Shimadzu GC-14B, respectively, with an electron capture detector after pre-concentration

104 by cryogenic methods for $\mathrm{SF}_{6}$ (Busenberg and Plummer, 1992) and CFCs (Busenberg and

105 Plummer, 2000). The detection limit of the CFC concentrations in water depended on the

106 standard CFCs gas or $\mathrm{SF}_{6}$ gas concentrations used for the calibration curve. The limit was $\sim 0.1$

$107 \mathrm{pg} / \mathrm{L}(0.01 \mathrm{pmol} / \mathrm{L})$ for the $\mathrm{CFCs}$ and $\sim 0.1 \mathrm{fg} / \mathrm{L}(0.01 \mathrm{fmol} / \mathrm{L})$ for the $\mathrm{SF}_{6}$. The major and trace

108 elements were analyzed with inductively coupled plasma-mass spectrometry (ICP-MS: Agilent

$1097500 \mathrm{cx}$ ) with a detection limit of minimum 0.1 parts per trillion (ppt). The values for $\delta \mathrm{D}$ and

$110 \delta^{18} \mathrm{O}$ were determined by the $\delta \mathrm{D} / \delta^{18} \mathrm{O}$ Isotopic Water Analyzer (Picarro L2130-i) with an 
111 accuracy of $0.1 \%$ and $0.02 \%$, respectively. The alkalinity was measured by titration against

$1120.02 \mathrm{~N} \mathrm{HCl}$ using a mixture of bromcresol green and methyl red (BCG-MR) as the indicator

113 ( $\mathrm{pH} 4.8$ ). Major anions, $\mathrm{Cl}^{-}, \mathrm{NO}_{3}^{-}$, and $\mathrm{SO}_{4}^{2-}$, were determined in the laboratory by ion

114 chromatography (PIA-1000, Shimadzu) with a detection limit of less than $0.1 \mathrm{mg} / \mathrm{L}$.

115

$116 \quad$ 3. Results

$1173.1 \quad$ Recharge area, recharge temperature, and residence time of spring water

118 Figure 2a shows the delta-diagram, the relationship between the observed hydrogen and the

119 oxygen stable isotopic ratios $\left(\delta \mathrm{D}\right.$ and $\left.\delta^{18} \mathrm{O}\right)$ of the 17 spring waters (Table 2$)$ and the 25 river

120 waters with two terrestrial meteoric lines, which are $\delta \mathrm{D}=8 \delta^{18} \mathrm{O}+10$ on the Pacific Ocean side

121 (Craig, 1961) and $\delta \mathrm{D}=8 \delta^{18} \mathrm{O}+17$ on the Sea of Japan side (Matsubaya et al., 1973). $\delta \mathrm{D}$ and

$122 \quad \underline{\delta^{18} \mathrm{O} \text { are plotted around a line, expressed by } \delta \mathrm{D}=5.85 \delta^{18} \mathrm{O}-12.6 \text {, between the two meteoric }}$

123 lines, indicating that the origin of the spring water and the river water is local meteoric water

124 affected by rain and vapor from the Pacific Ocean and the Sea of Japan. Figure 2b shows the

125 relationship between $\delta^{18} \mathrm{O}$ and the two altitudes at the sampling point and at the starting point of

126 the river water with those of the $\delta^{18} \mathrm{O}$ in Central Japan (Waseda and Nakai, 1983). This river

127 water follows the general, isotopic altitude effect of $\delta^{18} \mathrm{O}$ in Central Japan (Waseda and Nakai, 128 1983).

129 As shown in Table 2, the spring water is presumed to be originally recharged at $1,340 \mathrm{~m}$ to $1302,150 \mathrm{~m}$ a. s. $1 .\left(\mathrm{H}^{*}\right)$ in average altitude and to be $8 \cdot 3^{\circ} \mathrm{C}$ to $5 \cdot 4^{\circ} \mathrm{C}$ in average recharge temperature $131\left(\mathrm{~T}^{* *}\right)$ from the observed hydrogen and oxygen stable isotopic ratios $\left(\delta \mathrm{D}\right.$ and $\left.\delta^{18} \mathrm{O}\right)$ using the 132 isotopic altitude effect of $\delta^{18} \mathrm{O}$ in Central Japan (Waseda and Nakai, 1983; Komiya et al., 2003; 
Nakaya et al., 2007) and the spring water temperature (Fig. 2). Therefore, the location of each

134 recharge zone of spring water can be estimated by tracing back from the location of the spring to

135 the recharge altitude $\mathrm{H}^{*}$ along the topography. Referring to the mountain's slope, groundwater is

136 estimated to migrate a minimum distance of about $2.8 \mathrm{~km}$ and a maximum distance of about 10

$137 \mathrm{~km}$ through the aquifer between the recharge zone and the spring. Figure 3 shows the

138 relationship among $\mathrm{CFC}-12, \mathrm{CFC}-113$, and $\mathrm{SF}_{6}$, converted to atmospheric concentration by

139 Henry's law under the recharge temperature and the recharge altitude (Wanninkhof et al., 1991;

140 Busenberg and Plummer, 1992; Busenberg and Plummer, 2000), with a line for the piston flow

141 model for which the hydraulic head of the new recharge groundwater can induce the movement

142 of the old groundwater without mixing. As each relationship among CFC-12, CFC-113, and $\mathrm{SF}_{6}$

143 is fitted to each line of the piston flow model (Fig. 3), the groundwater flow is presumed to be a

144 piston flow. When defining the residence time as the arrival time of the groundwater from the

145 recharge zone to the spring through the aquifer, the groundwater residence time is calculated by

146 simply obtaining the difference between the sampling time and the recharge time measured by

147 the dating tracer for the groundwater in the case of a piston flow. The residence times for the 148 spring water samples range from 17 years to 45 years according to three dating tracers (Table 2).

149 From the migration distance of the spring water and the groundwater residence time, described 150 above, the groundwater migration velocity lies in the range of approximately $120 \mathrm{~m} / \mathrm{yr}$ to 550 $151 \mathrm{~m} / \mathrm{yr}$. In this study area, the concentrations of more than 40 trace elements, including Cs, were 152 also detected for each filtered $(0.2 \mu \mathrm{m})$ spring water sample (Fig. 1). As a result, a water source 153 area within the Yatsugatake Mountains provides a unique field for studying the longtime 154 behavior of field sorption-desorption reactions onto mineral surfaces of some trace elements in 
155 flowing groundwater through chemical weathering with groundwater residence times in the

156 natural water cycle in a confined aquifer composed originally of the same Quaternary volcanic 157 rock, pyroclastics, and lava layers (Kumai, 1981; Nishiki et al., 2007; Nishiki et al., 2012) with 158 little anthropogenic pollution.

159

$160 \quad 3.2 \quad$ Longtime behavior of several trace elements including Cesium

161 The $\mathrm{pH}$ of the spring water samples shows a tendency to increase with the residence time 162 (Tables 1 and 2). In general, the temporal decrease in groundwater $\mathrm{H}^{+}$, produced by the reaction 163 between $\mathrm{H}_{2} \mathrm{O}$ and $\mathrm{CO}_{2}$, suggests the temporal increase in the major cation in the groundwater by 164 the cation-exchange reaction between the groundwater and the silicate minerals composing the 165 volcanic rocks through chemical weathering. While the $\mathrm{SiO}_{2}$ in the groundwater is apparently 166 close to saturation with the dissolution of the silicate minerals, both major and trace elements, such as total cation, $\mathrm{Ca}, \mathrm{Mg}, \mathrm{As}, \mathrm{Ge}$, and $\mathrm{P}$, but excluding $\mathrm{Cs}$ in the spring water, increase in concentration due to the dissolution of the silicate minerals in the range of $5^{\circ} \mathrm{C}$ to $15^{\circ} \mathrm{C}$ in water 169 temperature (Fig. 4 and Tables 1 and 2). It is an important feature that the concentration of Cs 170 does not correlate with $\mathrm{SiO}_{2}$, even though $\mathrm{Cs}$ was once released from the $\mathrm{SiO}_{2} \underline{\text { mineral that }}$ 171 included Cs. Concentration of $\mathrm{Cs}$ in the flowing groundwater cannot be explained by the 172 dissolution of the silicate.

173 Groundwater cesium $\left(\mathrm{Cs}^{+}\right)$, belonging to the alkaline metal group, indicates a negative 174 correlation coefficient $\gamma$ with the apparent groundwater residence time, measured by $\mathrm{SF}_{6}$ dating 175 of the spring water, despite the fact that $\mathrm{Li}, \mathrm{Na}$, and $\mathrm{K}$ (alkaline metal group) indicate a weak 176 positive correlation with the groundwater residence time (Fig. 5a). The $\gamma$ order is $\mathrm{Na}^{+}>\mathrm{Li}^{+}>\mathrm{K}^{+}$ 
$177>\mathrm{Rb}^{+}>\mathrm{Cs}^{+}$for the aquifer in this study region. Ions of the alkaline metal group, excluding Fr, 178 apparently show a reverse trend in terms of the relationship between correlation coefficient and 179 the ionic radius. This $\gamma$ order may be related to the replacement series $\mathrm{Cs}^{+}>\mathrm{K}^{+}>\mathrm{Na}^{+}>\mathrm{Li}^{+}$ 180 based on the ion exchange capacity in the water-rock interaction (e.g., Ames, 1960). Moreover, a 181 noteworthy point is that Cs indicates a stronger negative correlation with the groundwater 182 residence time, while trace elements $\mathrm{P}, \mathrm{V}, \mathrm{Ga}$, and $\mathrm{Ge}$ indicate a stronger positive correlation (Fig. 183 5a). To understand the longtime behavior of $\mathrm{Cs}$ in spring water, a comparison of Cs with $\mathrm{P}, \mathrm{V}, \mathrm{Ga}$, 184 and Ge will be an effective means, considering the conflicting longtime behavior between 185 groundwater $\mathrm{Cs}$ and, $\mathrm{P}, \mathrm{V}, \mathrm{Ga}$, and $\mathrm{Ge}$. The $\mathrm{P}, \mathrm{V}, \mathrm{Ga}$, and $\mathrm{Ge}$, dissolving as an anion or a hydrate 186 (nonionic soluble species) in the groundwater, according to the redox (Eh-pH) diagram 187 (Schweitzer and Pesterfield, 2010) (Table 1), are more than 0.7 in correlation coefficient $(\gamma)$ 188 between the concentration and the groundwater residence time. Therefore, Figure 5 shows the 189 notable feature that as the groundwater residence time increases from 15 to 45 years, the groundwater Cs decreases exponentially in concentration, while $\mathrm{P}, \mathrm{V}, \mathrm{Ga}$, and Ge increase in the

191 spring water. The temporal increase in concentrations of groundwater trace elements, such as $\mathrm{P}$, $192 \mathrm{~V}, \mathrm{Ga}$, and Ge, indicates the release associated with the dissolution of silicate minerals through 193 chemical weathering.

194 Although groundwater Cs would increase in concentration in the initial mineral dissolution 195 phase through chemical weathering, the Cs gradually decreases in concentration for 45 years in 196 groundwater residence time through the rock-water interaction, despite the reaction that the 197 several trace elements in the groundwater increase with the groundwater residence time. As the 198 redox diagram indicates that $\mathrm{Cs}^{+}$is highly stable in resisting both oxidation and reduction 
199 (Schweitzer and Pesterfield, 2010), one of the reasons why only the groundwater Cs decreases

200 in concentration with residence time in the alkaline metal group may be the Cs sorption onto 201 aquifer minerals based on its having a larger cation-exchange capacity (Comans et al., 1989)

202 than other lighter metals in the alkaline metal group. However, Cs sorption onto an aquifer in the 203 Quaternary volcanic area requires a long residence time in the natural water cycle.

205 4. Discussion

$206 \quad 4.1 \quad$ Relationship between concentration of trace elements, and temperature and $\mathrm{pH}$

207 The concentrations of several major and trace elements, such as total cation, $\mathrm{Ca}, \mathrm{Mg}, \mathrm{As}$, and $\mathrm{Ge}$, 208 as well as $\mathrm{SiO}_{2}$ (Fig. 4a), in the spring water also apparently correlate weakly with the water 209 temperature, while the concentration of Cs does not correlate with the water temperature (Fig. 6).

210 The dissolution of silicate minerals, in general, proceeds with the equilibrium influenced by the 211 water temperature. In this study area, the water temperature depends on the altitude (Fig. 2c), 212 and the residence time of the spring water sampled at a lower altitude is likely to be longer than 213 that sampled at a higher altitude (Tables 1 and 2). As the spring water has a longer residence 214 time, and therefore, a higher temperature, it is not easy to figure out whether the concentration of 215 some trace elements is determined by the water temperature or by the residence time. In the 216 hydrogeological setting of this study area, both the temperature and the residence time cause 217 some trace elements to increase in concentration. However, the concentration of cesium is not 218 associated with temperature in the range of water temperature of $5^{\circ} \mathrm{C}$ to $15^{\circ} \mathrm{C}$ in the 219 groundwater, since the concentration of Cs does not apparently correlate with the water 220 temperature (Fig. 6e), as is the case for $\mathrm{SiO}_{2}$ as well (Fig. 4a), and it correlates negatively with 
the residence time (Fig. 5).

222 Many trace element concentrations may be controlled by adsorption-desorption reactions at 223 the mineral surface, with the equilibrium strongly influenced by $\mathrm{pH}$ (Elprince, 1978; Fuller and 224 Davis, 1989). Figure 7 shows the relationship between the concentration of several trace 225 elements and $\mathrm{pH}$. Since $\mathrm{Ge}, \mathrm{Ga}, \mathrm{P}$, and $\mathrm{V}$ weakly correlate with $\mathrm{pH}$, they may be influenced by $226 \mathrm{pH}$. However, since the $\mathrm{Ge}, \mathrm{Ga}, \mathrm{P}$, and $\mathrm{V}$ in groundwater dissolve into $\mathrm{H}_{2} \mathrm{GeO}_{3}, \mathrm{Ga}(\mathrm{OH})_{3}$, $227 \mathrm{H}_{2} \mathrm{PO}_{4}^{-}$or $\mathrm{HPO}_{4}{ }^{2-}$, and $\mathrm{H}_{2} \mathrm{VO}_{4}{ }^{-}$or $\mathrm{HVO}_{4}{ }^{2-}$, respectively, from the Eh-pH diagram (Schweitzer 228 and Pesterfield, 2010) (Table 1), desorption of P and V is likely to occur as $\mathrm{pH}$ increases with the 229 residence time. Although As weakly correlates with $\mathrm{pH}$, it is unclear whether As is controlled by $230 \mathrm{pH}$. Since Cs does not correlate with $\mathrm{pH}$ (Fig. 7a), the Cs is not controlled by $\mathrm{pH}$ in the range of $231 \mathrm{pH}$ of 6.7 to 8.5 in the groundwater. As the groundwater $\mathrm{Cs}$ is apparently independent of the $\mathrm{pH}$, $232 \mathrm{Cs}^{+}$adsorption onto the mineral surface should be small in comparison to the sorption of Cs. 233 Caron and Mankarios (2004) indicated that ${ }^{137} \mathrm{Cs}$ was predominantly in the anionic fraction, in 234 the larger-sized colloidal fraction, and in the strong-hydrophobic fraction of groundwater, 235 suggesting an association with natural organic matter (NOM). Some researchers also reported 236 that ${ }^{137} \mathrm{Cs}$ displayed a behavior consistent with a NOM association (e.g., Champ et al., 1984). 237 NOM may influence the long-term behavior of Cs. Considering the results described above, the 238 trace elements, excluding Cs, are likely to increase with water temperature and $\mathrm{pH}$ through the 239 water-rock interaction, while it is natural view that $\mathrm{Cs}$ is not controlled by water temperature and $240 \mathrm{pH}$ in flowing groundwater in the mountain water source area.

$242 \quad 4.2 \quad$ Sorption of Cs on aquifer material in being coexistent with other ions 
Curti (1999) reported that partition coefficients on calcite increase logarithmically with the ionic

244 radius of the co-precipitated ions, based on a review of laboratory investigations and 245 geochemical data. According to Curti (1999), because the ionic radius of Cs is the largest in the 246 alkaline metal group, excluding Fr, not detected in this field, the sorption of Cs on the mineral 247 surface is expected to be larger than that of other alkaline metals. As water-rock interaction, in 248 general, promotes mineral dissolution and the release of trace elements with residence time 249 between the flowing groundwater and the aquifer, $\mathrm{Cs}^{+}$becomes coexistent with the other ions in 250 the groundwater. Fukui and Katsurayama (1976) reported that the competitive sorption between $251 \mathrm{Cs}^{+}$and other ions occurs through a saturated sandy layer, and that the univalent ion having a 252 larger ionic radius is more sorptive than the other ions in competitive sorption. When $\mathrm{Cs}^{+}$is coexistent with other ions in the groundwater, the Cs sorption onto the aquifer is, therefore, expected to be relatively stronger than that of other ions, even though the aquifer is not a sandy layer. Consequently, the strong sorption of Cs onto the aquifer should cause Cs removal from the negative correlation of less than -0.7 (Fig. $5 b$ ).

\subsection{Estimation of longtime behavior on radioactive Cesium} von Gunten et al. (1988) reported that when measuring the radioactive fall-out from the damaged nuclear power station at Chernobyl (USSR) in a shallow groundwater stream in May 
1986, Ru-103, I-131, and Te-132 were found in the water (filtrate $<0.05 \mu \mathrm{m}$ ) infiltrating into 266 the groundwater, while no Cs-134 or 137 was detected from wells at distances of $2.5 \mathrm{~m}$ and $5 \mathrm{~m}$ 267 from the river in which Cs-134 and 137 were detected. They also reported that very small 268 radioactivity was found on colloids $>0.05 \mu \mathrm{m}$. The data for Cs-134 and -137 indicate complete 269 sorption on the aquifer material during infiltration (von Gunten et al., 1988). On the other hand, 270 Kersting et al. (1999) reported that radionuclides, including Cs, observed in groundwater 271 samples from aquifers at the Nevada Test Site, $1.3 \mathrm{~km}$ north of the sample site, were associated with the colloidal fraction ( $>1 \mu \mathrm{m}, 50 \mathrm{~nm}-1 \mu \mathrm{m}, 7 \mathrm{~nm}-50 \mathrm{~nm},<7 \mathrm{~nm})$ of the groundwater. 273 The data demonstrate that Cs is not immobile in the subsurface, but can be transported over 274 significant distances (Kersting et al., 1999).

275 As described above, from the $\mathrm{CFCs}_{\text {and }} \mathrm{SF}_{6}$, which are derived from the atmosphere, and the $276 \delta \mathrm{D}$ and $\delta^{18} \mathrm{O}$ in the spring water, the spring water migrates a minimum distance of about $2.8 \mathrm{~km}$ and a maximum distance of about $10 \mathrm{~km}$ through the aquifer between the recharge zone and the spring for several decades. Therefore, the data presented here for Cs through a filter $(0.2 \mu \mathrm{m})$ in 279 the spring water of the Yatsugatake Mountains provide field evidence that Cs is mobilized over a 280 long distance $(\sim 10 \mathrm{~km})$ for several decades through volcanic rock aquifers. Assuming that the longtime behavior of $\mathrm{Cs}^{\mathrm{A}}$ in groundwater is the same as that of Cs (e.g., Cornell, 1993; Yoshida 282 et al., 2004), based on the relationship between the groundwater residence time and the concentration of $\mathrm{Cs}$ in the spring water, radioactive $\mathrm{Cs}$ in the groundwater in mountain water source areas may move along groundwater flow paths (Nakaya et al., 2011) and may decrease exponentially, at the rate of one-tenth in twenty-two years (Fig. 5b), by sorption onto the aquifer through the rock-water interaction, excluding radioactive decay. Laboratory results of $\mathrm{Cs}^{+}$ 
sorption to siliceous mudstone and to compacted sodium montmorillonite by through-diffusion 288 and batch sorption experiments under constant $\mathrm{pH}(7.0$ or 8.5$)$, constant temperature $\left(25^{\circ} \mathrm{C}\right)$, and aerobic conditions for over 100 days extrapolate that water $\mathrm{Cs}^{+}$decreased exponentially, at the rate of one-tenth in more than two years, in a competitive ion exchange (Tachi et al., 2011; Tachi and Yotsduji, 2014). The major difference in the sorption rate of Cs, between their results and our observation, is caused by the large differences between the permeable rocks (sorbent) and/or between the water conditions. However, their experimental results and transient diffusion model with Freundlich sorption qualitatively agree with our observed longtime behavior of $\mathrm{Cs}^{+}$ sorption onto a rock aquifer. Although the exponential water $\mathrm{Cs}^{+}$decreases due to the $\mathrm{Cs}^{+}$ sorption onto a permeable layer, this decrease in $\mathrm{Cs}^{+}$does not advance for a short term in the field, compared with the laboratory results for the $\mathrm{Cs}^{+}$sorption. Therefore, the long-term $(\sim 50$ yrs.) monitoring of groundwater active Cs is needed in mountain water source areas where radioactive cesium has been dispersed at the times of nuclear power plant accidents. When considering the geological disposal of water that includes active Cs, the artificial injection of active Cs into deep rock aquifers (Smith et al., 2001; Rumynina et al., 2005) may follow the longtime behavior of the Cs sorption observed in the volcanic rock aquifers.

\section{Conclusions}

As the sorption and desorption behavior of the $\mathrm{Cs}$ in groundwater should be equal to that of $\mathrm{Cs}^{\mathrm{A}}$,

306 the longtime behavior (10-50 yr) of the $\mathrm{Cs}^{\mathrm{A}}$ concentration in flowing groundwater through aquifers is expected to be obtainable by field monitoring the relationship between the Cs 
310 was measured with the groundwater residence time, in order to evaluate the longtime behavior

311 of $\mathrm{Cs}^{\mathrm{A}}$ in the flowing groundwater of an important source area for drinking water in terms of the

312 natural water cycle.

314 1) Groundwater Cs is mobile over a long distance $(\sim 10 \mathrm{~km})$ from the recharge area to the spring

315 for several decades through volcanic rock aquifers.

2) The Cs concentration in flowing groundwater exponentially decreases slowly with the groundwater residence time ( $\sim 5 \mathrm{yr}$ ), while several trace elements, namely, P, V, Ga, and Ge, increase in concentration with the groundwater residence time through chemical weathering.

3) The Cs, contained in flowing groundwater in mountain water source areas, decreases exponentially, at the rate of one-tenth in twenty-two years, by sorption onto the aquifer through rock-water interaction.

\section{Acknowledgements}

We thank Saku Water Supply Authority, Japan for cooperation in groundwater sampling. We also thank Research Institute for Humanity and Nature, Japan for use of $\delta \mathrm{D} / \delta^{18} \mathrm{O}$ Isotopic Water Analyzer and ICP-MS. The author thanks anonymous reviewers for useful remarks that improved the original manuscript, and Editor in Chief, Dr. Peter Goethals for valuable comments. This research was partly supported by a Grant-in-aid for Science Research, number 22560509, from the Japanese Ministry of Education, Science, Sports and Culture, and by a Grant-in-aid for A-STEP search type, number AS231Z02080C from Japan Science and Technology Agency. 
337 Ames, Jr., L. L., 1961. Cation sieve properties of the open zeolites chabazite, mordenite, erionite $338 \quad$ and clinoptilolite. Am. Mineral. 46, 1120-1131.

339 Buddemeier, R. W., Hunt, J. R., 1988. Transport of colloidal contaminants in groundwater:

$340 \quad$ radionuclide migration at the Nevada test site. Appl. Geochem. 3, 535-548.

341 Busenberg, E., Plummer, L. N., 2000. Dating young groundwater with sulfur hexafiuoride:

342 Natural and anthropogenic sources of sulfur hexafiuoride. Water Resour. Res. 36(10),

$343 \quad 3011-3030$.

344 Busenberg, E., Plummer, L. N., 1992. Use of chlorofluoromethanes (CC13F and CC12F2) as

345 hydrologic tracers and age-dating tools: The alluvium and terrace system of central

346 Oklahoma. Water Resour. Res. 28, 2257-2283.

347 Busenberg, E., Plummer, L. N., Cook, P. G., Solomon, D.K., Han, L.F., Gröning, M., Oster, H., 348 2006. Use of chlorofluorocarbons in hydrology: A Guidebook/ Chapter 12. Sampling and 349 analytical methods. International Atomic Energy Agency, 199-220.

350 Cornell, R. M., 1993. Adsorption of cesium on minerals: A Review. Journal of Radio- analytical $351 \quad$ and Nuclear Chemistry. 171(2), 483-500.

352 Caron, F., Mankarios, G., 2004. Pre-assessment of the speciation of ${ }^{60} \mathrm{Co},{ }^{125} \mathrm{Sb},{ }^{137} \mathrm{Cs}$ and ${ }^{241} \mathrm{Am}$ 353 in a contaminated aquifer, J. Environ. Rad., 77, 29-46.

354 Champ, D.R., Young, J.L., Robertson, D.E., Abel, K.H., 1984. Chemical speciation of long355 lived radionuclides in a shallow groundwater flow system. Water Poll. Res. J. Can. 19(2), $356 \quad \underline{35-54}$. 
357 Comans, R. N. J., Haller, M., Preter, P. D., 1991. Sorption of cesium on illite: Non-equilibrium

358 behavior and reversibility. Geochim. Cosmochim. Acta 55, 433-440.

359 Comans, R. N. J., Middelburg, J. J., Zonderhuis, J., Woittiez, J. R. W., De Lange, G. J., Das,

360 H.A., Van Der Weijden, C. H., 1989. Mobilization of radiocaesium in pore water of lake

$361 \quad$ sediments. Nature 339, 367-369.

362 Curti, E., 1999. Coprecipitation of radionuclides with calcite: estimation of partition coefficients

363 based on a review of laboratory investigations and geochemical data. Appl. Geochem. 14, $364 \quad 433-445$.

365

366 Water. Resour. Res. 14(4), 696-698.

367 Francis, C.W., Brinkley, F. S., 1976. Preferential adsorption of ${ }^{137}$ Cs to micaceous minerals in 368 contaminated freshwater sediment. Nature 260, 511-513.

369 Fukui, M., Katsurayama, K., 1976. Studies on the sorption model of Cs and Sr ion through a

370 saturated sandy layer. Journal of JSCE 254, 37-48 (in Japanese).

371 Fuller, C. C., Davis, J. A., 1989. Influence of coupling of sorption and photosynthetic processes

372 on trace element cycles in natural waters. Nature $340,52-54$.

373 Kersting, A. B., Efurd, D. W., Finnegan, D. L., Rokop, D. J., Smith, D. K., Thompson, J. L., 374 1999. Migration of plutonium in ground water at the Nevada Test Site. Nature 397, 56-59.

375 Komiya, H., Nakaya, S., Masuda, H., Kusakabe, M., 2003. Groundwater flow system in the 376 central and south part of Matsumoto Basin, Nagano, estimated from oxygen and hydrogen 377 stable isotope ratios and water quality. J. Groundwater Hydrol. 45(2), 147 - 170 (in Japanese $378 \quad$ with English abstract.). 
Kumai, H., 1981. Hydrogeological study of the Yatsugatake volcanic terrain. J. Facul. Sci. Shinshu Univ. http://hdl.handle.net /10091/10682 (in Japanese with English abstract.).

Mizuno, T., Kubo, H., 2013. Overview of active cesium contamination of freshwater fish in Fukushima and eastern Japan. Scientific Reports 3: 1742. doi:10.1038/srep01742.

Nakaya, S., Natsume, H., Masuda, H., Mitamura, M., Biswas, D. K., Seddique, A. A., 2011. Effect of groundwater flow on forming arsenic contaminated groundwater in Sonargaon, Bangladesh. J. Hydrology 55(409), 724-736.

Nakaya, S., Uesugi, K., Motodate, Y., Ohmiya, I., Komiya, H., Masuda, H, Kusakabe, M., 2007. Spatial separation of groundwater flow paths from a multi-flow system by a simple mixing model using stable isotopes of oxygen and hydrogen as natural tracers. Water Resour. Res. 43. W09404, 1-15. doi:10.1029/2006WR005059.

Nishiki, K., Matsumoto, A., Uto, K., Takahashi, K., Miyake, Y., 2007. Reexamination of volcanic activity of Yabashira area, central Japan. J. Geol. Soc. Japan 113(5), 193-211 (in Japanese with English abstract.).

Nishiki, K., Takahashi, K., 2012. Geological history of the Yabashira volcanoes, central Japan. J. Geol. Soc. Japan 118(8), 499-515 (in Japanese with English abstract.).

Rumynina, V.G., Konosavskya, P.K., Hoehn, E., 2005. Experimental and modeling study of adsorption-desorption processes with application to a deep-well injection radioactive waste disposal site. J. Contam Hydrol. 76, 19-46.

Saiers, J. E., Hornberger, G. M., 1996. The role of colloidal kaolinite in the transport of cesium through laboratory sand columns. Water. Resour. Res. 32(1), 33-41. 
400 Schweitzer, G. K., Pesterfield, L. L., 2010. The aqueous chemistry of the elements. Oxford $401 \quad$ University Press, p.434.

402 Smith, P.A., Alexander, W.R., Kickmaier, W., Ota, K., Frieg, B., McKinley, I.G., 2001.

403 Development and testing of radionuclide transport models for fractured rock: examples from 404 the NagrarJNC Radionuclide Migration Programme in the Grimsel Test Site, Switzerland. J. $405 \quad$ Contam Hydrol. 47, 335-348.

406 Tachi, Y., Yotsuji, K., Seida, Y., Yui, M., 2011. Diffusion and sorption of $\mathrm{Cs}^{+}$, I ${ }^{-}$and HTO in 407 samples of the argillaceous Wakkanai Formation from the Horonobe URL, Japan:

408 Clay-based modeling approach. Geochim. Cosmochim. Acta 75, 6742-6759.

409 Tachi, Y., Yotsuji, K., 2014. Diffusion and sorption of $\mathrm{Cs}^{+}, \mathrm{Na}^{+}, \mathrm{I}^{-}$and $\mathrm{HTO}$ in compacted 410 sodium montmorillonite as a function of porewater salinity: Integrated sorption and diffusion 411 model. Water Research 132, 75-93.

412 Tsuji, H., Yasutaka, T., Kawabe, Y., Onishi, T., Komai, T., 2014. Distribution of dissolved and 413 particulate radiocesium concentrations along rivers and the relations between radiocesium 414 concentration and deposition after the nuclear power plant accident in Fukushima. Water $415 \quad$ Research 60, 15-27.

416 von Gunten, H. R., Waber, U. E., Krähenbühl, U, 1988. The reactor accident at Chernobyl: A 417 possibility to test colloid-controlled transport of radionuclides in a shallow aquifer. J. Contam $418 \quad$ Hydrol. 2, 237-247.

419 Wanninkhof, R., Ledwell, J. R., Watson, A. J., 1991. Analysis of sulfur hexafluoride in seawater. $420 \quad$ J. Geophys. Res. 96(C5), 8733-8740. 
421 Waseda, A., Nakai, N., 1983. Isotopic compositions of meteoric and surface waters in central

422 and north-east Japan. Chikyukagaku, 17, 83-91 (in Japanese with English abstract.).

423 Yoshida, S, Muramatsu, Y, Dvornik, A.M., Zhuchenko, T.A., Linkov, I., 2004. Equilibrium of

424 radiocesium with stable cesium within the biological cycle of contaminated forest

425 ecosystems. J. Environ. Radioact. 75, 301-313.

426

427 
428

429 Table 1 - Chemical parameters for spring water samples

430 in Yatsugatake Mountains, Nagano, Japan

431

\begin{tabular}{cccccccc}
\hline No & $\mathrm{H}$ & $\mathrm{T}$ & $\mathrm{pH}$ & $\mathrm{EC}$ & $\mathrm{DO}$ & ORP & Geological \\
& $(\mathrm{mASL})$ & $(\mathrm{C})$ & & $(\mu \mathrm{S} / \mathrm{cm})$ & $(\mathrm{mg} / \mathrm{L})$ & $(\mathrm{mV})$ & facies \\
\hline
\end{tabular}

\begin{tabular}{rrrrrrrl}
\hline 1 & 1,013 & 9.6 & 7.32 & 28.3 & 2.12 & 53.0 & pyroclastics \\
2 & 833 & 13.2 & 8.26 & 44.1 & 2.85 & -22.0 & pyroclastics \\
3 & 1,109 & 10.4 & 7.28 & 46.8 & 5.91 & 96.0 & pyroclastics \\
4 & 947 & 12.6 & 6.79 & 74.5 & 3.25 & -72.0 & pyroclastics \\
5 & 778 & 13.0 & 7.80 & 65.2 & 4.20 & 242 & pyroclastics \\
6 & 1,051 & 10.0 & 6.68 & 21.6 & 4.45 & 313 & pyroclastics \\
7 & 1,943 & 5.5 & 6.71 & 14.67 & 4.29 & 359 & Lava \\
8 & 971 & 11.2 & 8.42 & 42.7 & 3.58 & 359 & pyroclastics \\
9 & 879 & - & - & - & - & - & pyroclastics \\
10 & 1,187 & 9.9 & 7.03 & 38.7 & 4.82 & 313 & pyroclastics \\
11 & 1,224 & 10.3 & 8.01 & 35.2 & 3.95 & 282 & pyroclastics \\
12 & 1,246 & 9.3 & 7.35 & 30.5 & 4.79 & 276 & Lava \\
13 & 1,022 & 10.7 & 7.29 & 33.0 & 5.58 & 286 & Lava \\
14 & 835 & 12.5 & 7.04 & 53.8 & 3.75 & 289 & pyroclastics \\
15 & 820 & 14.9 & 8.49 & 54.0 & 2.99 & 2.60 & pyroclastics \\
16 & 799 & 14.3 & 7.75 & 75.7 & 4.25 & 282 & pyroclastics \\
17 & 1,215 & 8.8 & 6.89 & 26.8 & 4.85 & 258 & Lava \\
& & & & & & & \\
\hline
\end{tabular}

432

433

434

435

436

H: Altitude of sample point; T: Water temperature ; EC: Electrical conductivity; DO: Dissolved oxygen; ORP: Oxidation reduction potential; Eh of the redox diagram can be calculated using ORP and water temperature $(\mathrm{T})$ by

437 
439 Table 2 - Dating tracers and stable isotopes of oxygen and hydrogen for 440 spring water samples in Yatsugatake Mountains, Nagano, Japan

\begin{tabular}{|c|c|c|c|c|c|c|c|c|c|c|}
\hline No & $\begin{array}{c}\mathrm{SF}_{6} \\
(\mathrm{fg} / \mathrm{L})\end{array}$ & $\begin{array}{c}\text { CFC } \\
-12 \\
(\mathrm{pg} / \mathrm{L})\end{array}$ & $\begin{array}{l}\text { CFC } \\
-113 \\
(\mathrm{pg} / \mathrm{L})\end{array}$ & $\begin{array}{c}\mathrm{t}_{6} \\
(\mathrm{yr})\end{array}$ & $\begin{array}{l}\mathrm{t}_{12} \\
\text { (yr) }\end{array}$ & $\begin{array}{l}\mathrm{t}_{113} \\
\text { (yr) }\end{array}$ & $\begin{array}{c}{ }^{18} \mathrm{O} \\
\text { (\%o versus } \\
\text { VSMOW) }\end{array}$ & $\begin{array}{c}\text { D } \\
\text { (\%o versus } \\
\text { VSMOW) }\end{array}$ & $\begin{array}{c}\mathrm{H}^{*} \\
(\mathrm{~m} \\
\text { ASL) }\end{array}$ & $\begin{array}{l}\mathrm{T}^{* * *} \\
\left({ }^{\circ} \mathrm{C}\right)\end{array}$ \\
\hline 1 & 181 & 304 & 53.1 & 17.2 & 22.0 & 25.6 & -12.72 & -87.24 & 1,770 & 6.2 \\
\hline 2 & 9.14 & 76.1 & 1.78 & 43.0 & 41.1 & 44.4 & -11.97 & -83.14 & 1,446 & 7.7 \\
\hline 3 & 45.0 & 144 & 28.4 & 31.2 & 35.4 & 30.2 & -12.29 & -84.55 & 1,583 & 7.0 \\
\hline 4 & 87.8 & 639 & 17.8 & 25.2 & OR & 33.1 & -11.72 & -81.45 & 1,341 & 8.3 \\
\hline 5 & 14.3 & 44.6 & 0. & 39.8 & 45.3 & $>45$ & -12.19 & -84.97 & 1,540 & 7.2 \\
\hline 6 & 85.6 & 298 & 86.9 & 25.4 & 20.9 & 20.0 & -11.74 & -81.07 & 1,349 & 8.2 \\
\hline 7 & 98.9 & 298 & 92.8 & 24.6 & 22.9 & 20.9 & -13.13 & -88.86 & 2,150 & $<5.4$ \\
\hline 8 & 13.1 & 140 & 19.6 & 40.5 & 35.7 & 32.7 & -12.17 & -84.66 & 1,533 & 7.2 \\
\hline 9 & 11.8 & 82.4 & 10.5 & 41.2 & 40.3 & 36.4 & -11.84 & -82.93 & 1,390 & 8.0 \\
\hline 10 & 104 & 391 & 79.5 & 23.5 & OR & 21.6 & -11.88 & -81.49 & 1,410 & 7.9 \\
\hline 11 & 58.6 & - & 46.0 & 29.4 & - & 26.8 & -12.92 & -89.27 & 1,854 & 5.8 \\
\hline 12 & 97.9 & 387 & 72.6 & 24.5 & OR & 23.1 & -12.52 & -85.75 & 1,682 & 6.5 \\
\hline 13 & 87.1 & 272 & 129 & 25.5 & 23.9 & OR & -12.12 & -83.17 & 1,513 & 7.3 \\
\hline 14 & 66.1 & 553 & 68.5 & 28.0 & OR & 23.0 & -11.77 & -81.80 & 1,362 & 8.1 \\
\hline 15 & 50.3 & 352 & 34.2 & 30.3 & OR & 28.5 & -11.91 & -81.97 & 1,422 & 7.8 \\
\hline 16 & 26.2 & 60.9 & - & 35.1 & 43.0 & - & -12.28 & -85.09 & 1,583 & 7.0 \\
\hline 17 & 131 & 305 & 74.4 & 21.1 & 22.0 & 22.0 & -12.71 & -87.47 & 1,764 & 6.2 \\
\hline
\end{tabular}

$443 \mathrm{H}^{*}$ is the estimated mean recharge altitude and $\mathrm{T}^{* *}$ is the water temperature estimated at $\mathrm{H}^{*}$ from $\delta^{18} \mathrm{O}$ and

$444 \delta \mathrm{D}$ and its altitude effect ${ }^{9-11}$ (Supplementary Fig. 1). $\mathrm{t}_{6}, \mathrm{t}_{12}$ and $\mathrm{t}_{113}$ represent the residence times determined

445 from dating tracers $\mathrm{SF}_{6}, \mathrm{CFC}-12$, and CFC-113, respectively. Henry's law is applied to the dating under

$446\left(\mathrm{~T}^{* *}, \mathrm{H}^{*}\right)$ condition $^{22,23}$. OR (: over record) indicates that the residence time cannot be determined, because 
450

451

452

453

Table 3 - Major components for spring water samples in Yatsugatake Mountains, Nagano, Japan

\begin{tabular}{|c|c|c|c|c|c|c|c|c|c|c|c|}
\hline No & $\begin{array}{c}\text { Alk } \\
(\mathrm{meq} / \mathrm{L}) \\
<0.004\end{array}$ & $\begin{array}{c}\mathrm{Cl}^{-} \\
(\mathrm{mg} / \mathrm{L}) \\
<0.1\end{array}$ & $\begin{array}{c}\mathrm{SO}_{4}^{2-} \\
(\mathrm{mg} / \mathrm{L}) \\
<0.1\end{array}$ & $\begin{array}{c}\mathrm{NO}_{3}^{-} \\
(\mathrm{mg} / \mathrm{L}) \\
<0.1\end{array}$ & $\begin{array}{l}\mathrm{Na}^{+} \\
(\mathrm{mg} / \mathrm{L}) \\
<0.04\end{array}$ & $\begin{array}{l}\mathrm{K}^{+} \\
(\mathrm{mg} / \mathrm{L}) \\
<0.04\end{array}$ & $\begin{array}{l}\mathrm{Ca}^{2+} \\
(\mathrm{mg} / \mathrm{L}) \\
<0.01\end{array}$ & $\begin{array}{l}\mathrm{Mg}^{2+} \\
(\mathrm{mg} / \mathrm{L}) \\
<0.003\end{array}$ & $\begin{array}{c}\text { Total } \\
\text { Cation } \\
(\mathrm{meq} / \mathrm{L})\end{array}$ & $\begin{array}{c}\text { Total } \\
\text { Anion } \\
(\mathrm{meq} / \mathrm{L})\end{array}$ & $\begin{array}{l}\mathrm{SiO}_{2} \\
(\mathrm{mg} / \mathrm{L}) \\
<0.02\end{array}$ \\
\hline 1 & 0.284 & 1.2 & 1.5 & 0.9 & 2.53 & 1.34 & 3.84 & 0.986 & 0.387 & 0.382 & 26.52 \\
\hline 2 & 0.516 & 0.3 & 0.3 & 0.4 & 3.75 & 1.31 & 5.99 & 1.786 & 0.580 & 0.541 & 29.80 \\
\hline 3 & 0.532 & 0.3 & 0.5 & 0.9 & 3.27 & 1.42 & 5.98 & 1.695 & 0.534 & 0.566 & 31.59 \\
\hline 4 & 0.478 & 4.1 & 0.5 & 17.9 & 3.66 & 1.68 & 8.91 & 3.272 & 0.950 & 0.893 & 28.41 \\
\hline 5 & 0.698 & 1.5 & 0.9 & 0.8 & 6.00 & 2.14 & 8.01 & 2.931 & 0.880 & 0.771 & 34.86 \\
\hline 6 & 0.282 & 0.1 & 0.1 & 0.9 & 2.03 & 0.77 & 3.12 & 0.678 & 0.299 & 0.302 & 21.38 \\
\hline 7 & 0.210 & 0.1 & 0.5 & 0.2 & 1.38 & 0.71 & 2.30 & 0.643 & 0.255 & 0.227 & 15.00 \\
\hline 8 & 0.542 & 0.2 & 0.7 & 2.2 & 3.54 & 1.32 & 6.06 & 1.729 & 0.628 & 0.597 & 28.32 \\
\hline 9 & 0.546 & 0.1 & 0.8 & 0.7 & 3.09 & 1.16 & 6.05 & 1.742 & 0.615 & 0.578 & 28.53 \\
\hline 10 & 0.436 & 0.7 & 0.1 & 1.8 & 2.43 & 0.76 & 6.11 & 1.753 & 0.570 & 0.489 & 18.85 \\
\hline 11 & 0.462 & 0.1 & 0.9 & 0.5 & 2.91 & 1.49 & 4.80 & 1.503 & 0.516 & 0.492 & 29.90 \\
\hline 12 & 0.404 & 0.1 & 1.0 & 0.7 & 2.21 & 1.07 & 4.78 & 1.372 & 0.475 & 0.438 & 22.06 \\
\hline 13 & 0.418 & 0.2 & 0.8 & 1.1 & 2.76 & 1.35 & 4.10 & 1.502 & 0.480 & 0.457 & 27.97 \\
\hline 14 & 0.540 & 0.5 & 1.3 & 5.2 & 3.71 & 1.45 & 7.41 & 2.260 & 0.753 & 0.665 & 28.73 \\
\hline 15 & 0.654 & 0.2 & 0.8 & 2.9 & 3.78 & 1.52 & 7.24 & 1.969 & 0.716 & 0.721 & 29.59 \\
\hline 16 & 0.874 & 0.6 & 1.4 & 2.7 & 7.69 & 2.64 & 8.67 & 3.441 & 1.03 & 0.965 & 33.23 \\
\hline 17 & 0.310 & 0.2 & 0.9 & 0.0 & 2.42 & 1.43 & 3.80 & 0.880 & 0.392 & 0.335 & 26.35 \\
\hline
\end{tabular}


458 Table 4 - Concentrations of several trace elements

459 for spring water samples in Yatsugatake

460 Mountains, Nagano, Japan

\begin{tabular}{|c|c|c|c|c|c|c|}
\hline No & $\begin{array}{c}\text { Cs } \\
(\mu \mathrm{g} / \mathrm{L})\end{array}$ & $\begin{array}{c}P \\
(\mu \mathrm{g} / \mathrm{L})\end{array}$ & $\begin{array}{l}\mathrm{V} \\
(\mu \mathrm{g} / \mathrm{L})\end{array}$ & $\begin{array}{c}\mathrm{Ge} \\
(\mu \mathrm{g} / \mathrm{L})\end{array}$ & $\begin{array}{c}\mathrm{Ga} \\
(\mu \mathrm{g} / \mathrm{L})\end{array}$ & $\begin{array}{c}\text { As } \\
(\mu \mathrm{g} / \mathrm{L})\end{array}$ \\
\hline$*$ & $<0.004$ & $<5$ & $<0.004$ & $<0.001$ & $<0.0005$ & $<0.004$ \\
\hline 1 & 0.129 & 14 & 3.168 & 0.012 & 0.0090 & 0.204 \\
\hline 2 & 0.019 & 77 & 17.43 & 0.048 & 0.0580 & 0.403 \\
\hline 3 & 0.029 & 72 & 13.01 & 0.031 & 0.0110 & 0.283 \\
\hline 4 & 0.068 & 4.0 & 1.448 & 0.013 & 0.0 & 0.194 \\
\hline 5 & 0.038 & 65 & 13.29 & 0.043 & 0.0190 & 0.449 \\
\hline 6 & 0.079 & 37 & 1.047 & 0.007 & 0.0145 & 0.147 \\
\hline 7 & 0.079 & 5.0 & 0.211 & 0.006 & 0.0015 & 0.160 \\
\hline 8 & 0.020 & 80 & 13.02 & 0.030 & 0.0375 & 0.306 \\
\hline 9 & 0.015 & 90 & 16.50 & 0.038 & 0.0249 & 0.191 \\
\hline 10 & 0.043 & 19 & 2.838 & 0.010 & 0.0131 & 0.0710 \\
\hline 11 & 0.063 & 67 & 12.31 & 0.023 & 0.0125 & 0.404 \\
\hline 12 & 0.040 & 43 & 6.578 & 0.018 & 0.0155 & 0.165 \\
\hline 13 & 0.090 & 62 & 6.106 & 0.020 & 0.00820 & 0.302 \\
\hline 14 & 0.088 & 32 & 4.772 & 0.021 & 0.0050 & 0.341 \\
\hline 15 & 0.077 & 58 & 8.750 & 0.032 & 0.0131 & 0.343 \\
\hline 16 & 0.035 & 89 & 15.95 & 0.049 & 0.0141 & 0.539 \\
\hline 17 & 0.173 & 28 & 4.874 & 0.008 & 0.0035 & 0.278 \\
\hline
\end{tabular}

462 *) lower quantification limit 


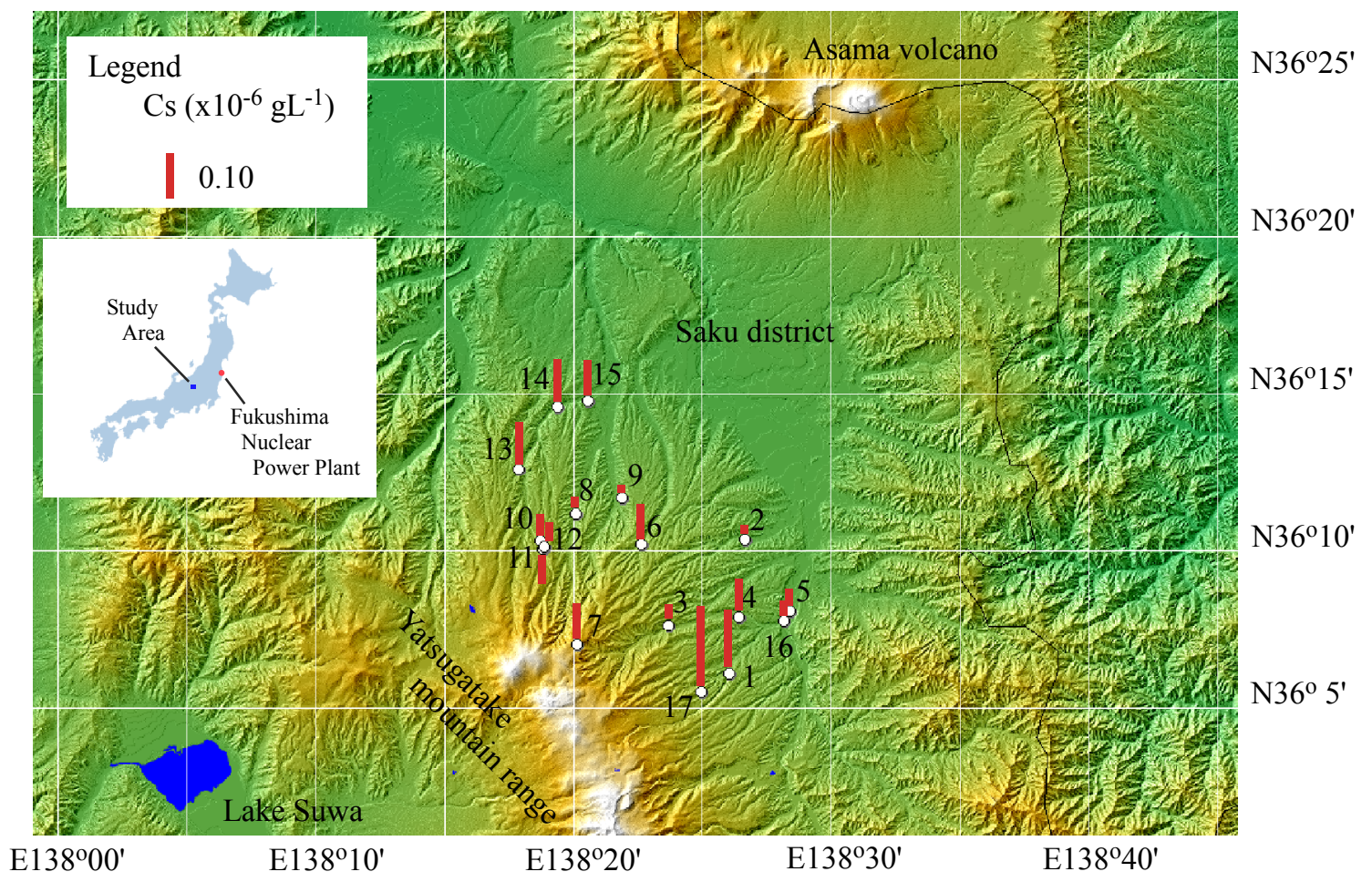

Fig. 1 - Study area. Circles indicate sample locations of spring waters. Bars denote cesium concentration of the spring water samples. 


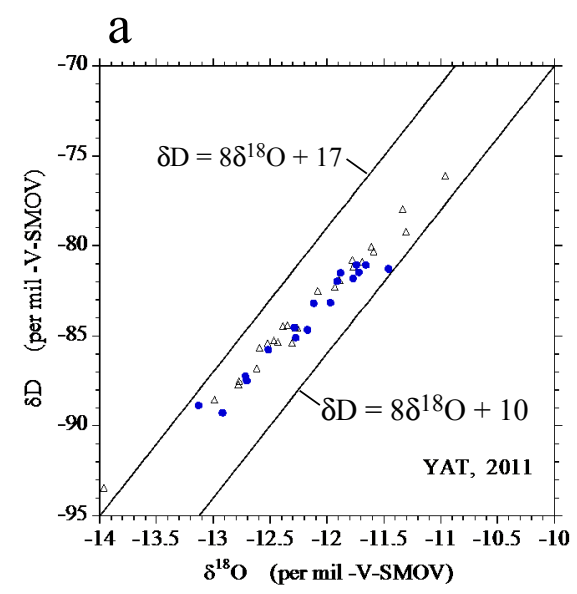

- spring water

$\Delta$ surface water
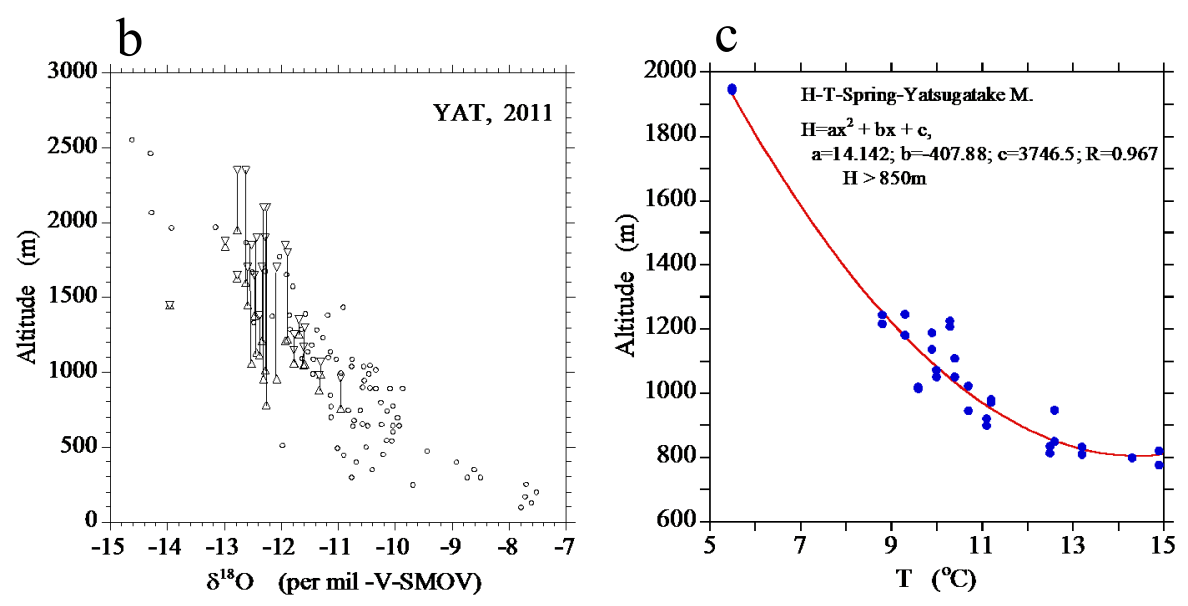

O from (Waseda and Nakai, 1983)

$\nabla$ altitude of top of the river

$\Delta$ altitude of sampling point

Fig. 2 - Sources of the spring water samples and the surface water samples. Relationship between hydrogen and oxygen stable isotopic ratios $\left(\delta \mathrm{D}, \delta^{18} \mathrm{O}\right)(\mathrm{a})$, altitude versus $\delta^{18} \mathrm{O}$ for surface water (b), and altitude versus spring water temperature $\mathrm{T}(\mathrm{c})$. 
$\mathbf{a}$

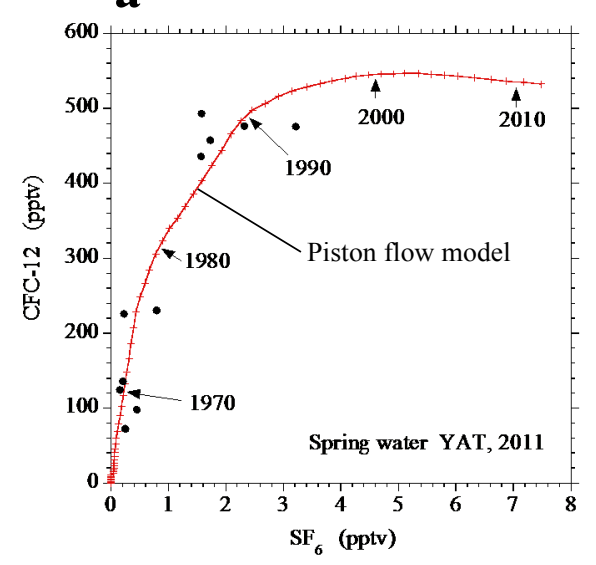

b

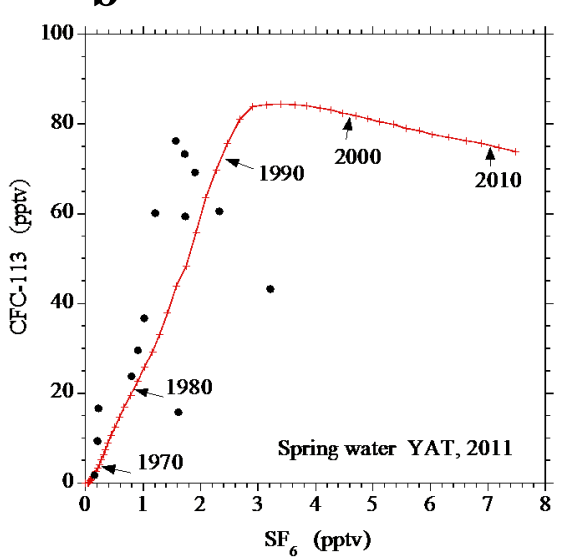

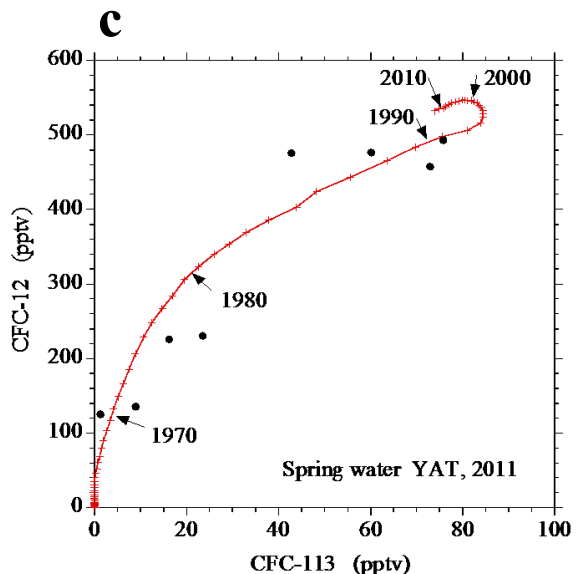

Fig. 3 - Dating tracers SF6, CFC-12, and CFC-113 concentrations in spring water samples. The concentrations are given in equivalent atmospheric concentrations (pptv). a, CFC-12 versus SF6; b, CFC-113 versus SF6; c, CFC-12 versus CFC-113. Solid curves indicate theoretical curves for the piston flow model. Numbers show the recharge ages of groundwater, in years (yr). 

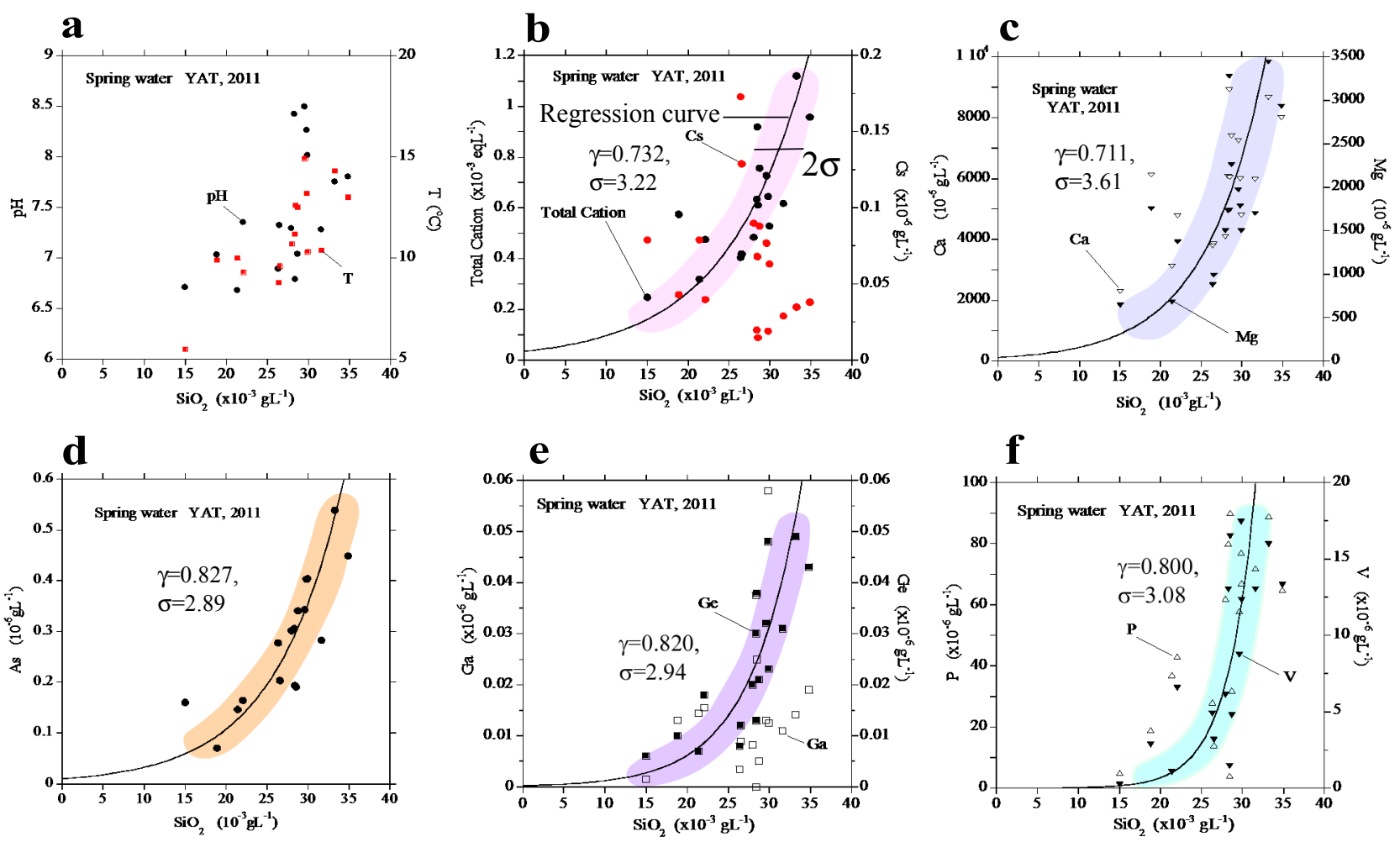

Fig. 4 - Relationship between concentrations of major and trace elements, and $\mathrm{SiO}_{2}$ in spring water samples, with the dissolution of the silicate minerals. a, $\mathrm{pH}$ (black solid circle) and water temperature (red solid square) versus $\mathrm{SiO}_{2}$; b, Total cation (black solid circle) and $\mathrm{Cs}$ (red solid circle) versus $\mathrm{SiO}_{2}$, regression curve (R.C.) : $\mathrm{SiO}_{2}=32.9+22.5 \log$ (Total Cation) ; c, $\mathrm{Ca}$ (open triangle) and $\mathrm{Mg}$ (solid triangle) versus $\mathrm{SiO}_{2}$, R.C. : $\mathrm{SiO}_{2}=-27.7+17.1 \mathrm{log}(\mathrm{Mg})$; d, As versus $\mathrm{SiO}_{2}$, R.C. : $\mathrm{SiO}_{2}=38.6+19.2 \log (\mathrm{As})$; e, $\mathrm{Ga}$ (open square) and $\mathrm{Ge}$ (solid square) versus $\mathrm{SiO}_{2}, \mathrm{R}^{\mathrm{C}}$. : $\mathrm{SiO}_{2}=$ $51.3+14.1 \log (\mathrm{Ge})$; f, $\mathrm{P}$ (open triangle) and $\mathrm{V}$ (solid triangle) versus $\mathrm{SiO}_{2}$, R.C. : $\mathrm{SiO}_{2}=21.3+7.92 \log (\mathrm{V})$. 

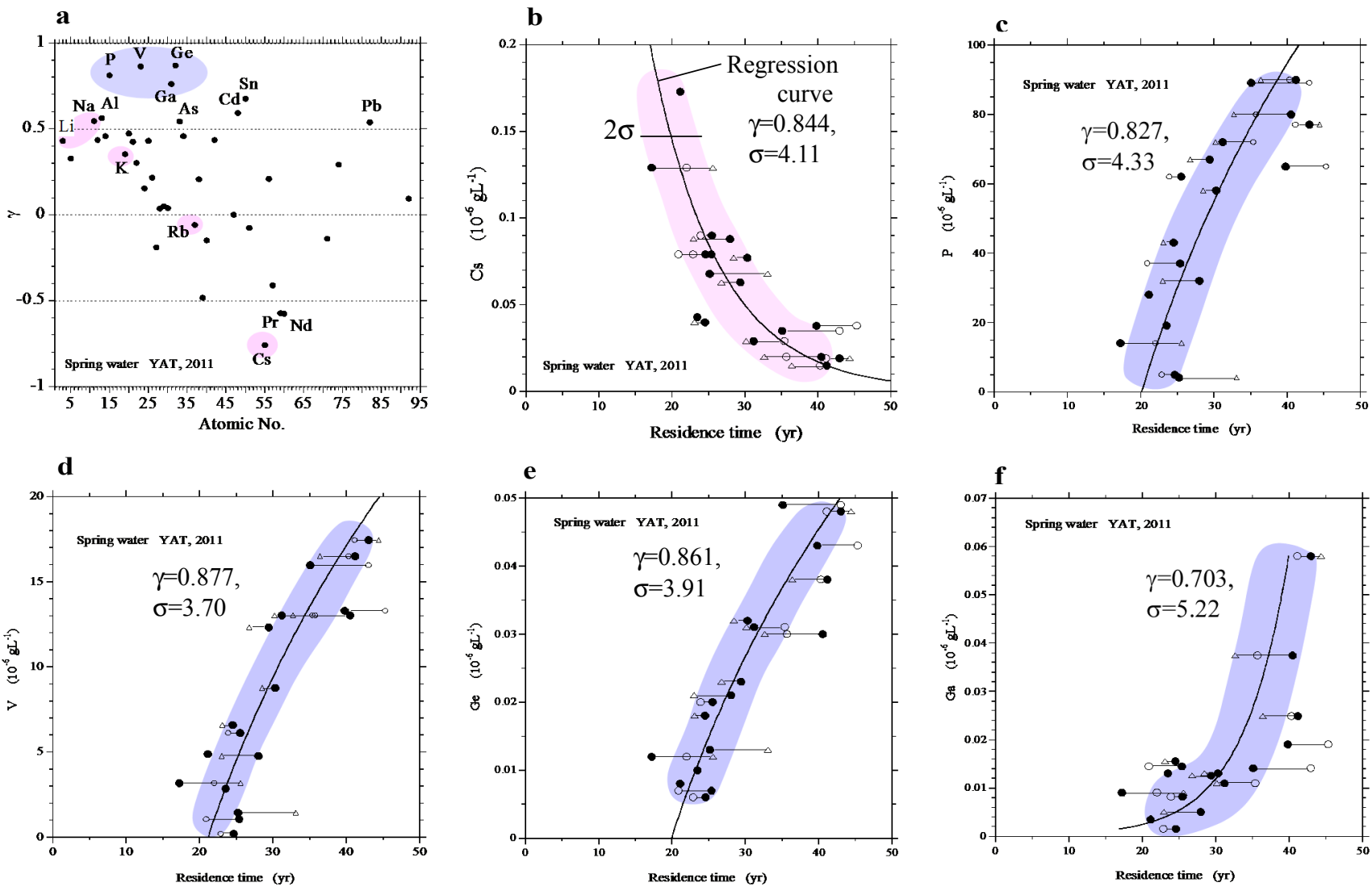

\section{$\mathrm{SF}_{6} \quad \mathrm{O}_{\mathrm{CFC}-12} \quad \Delta \mathrm{CFC}-113$}

Fig. 5 - Relationship between the concentration of element and the groundwater residence time. Correlation coefficients $(\gamma)$ between the concentration of element and the groundwater residence time, measured by $\mathrm{SF}_{6}$ dating, for atomic number in the spring water samples (a). Relationship between the groundwater residence time and the groundwater Cs concentration (b), P concentration (c), V concentration (d), Ge concentration (e), and Ga concentration (f) of the spring water samples. Regression curves are (b) Residence time by $\mathrm{SF}_{6} \mathrm{t}_{6}=2.00-21.6 \log (\mathrm{Cs}) ;(\mathrm{c}) \mathrm{t}_{6}=20.1 \exp (0.00727 \mathrm{P}) ;(\mathrm{d}) \mathrm{t}_{6}=$ $21.2 \exp (0.0372 \mathrm{~V})$; (e) $\mathrm{t}_{6}=19.9 \exp (15.4 \mathrm{Ge})$; (f) $\mathrm{t}_{6}=57.9+14.5 \log (\mathrm{Ga})$. The lines connected to the symbols indicate the residence time results for the same water. 

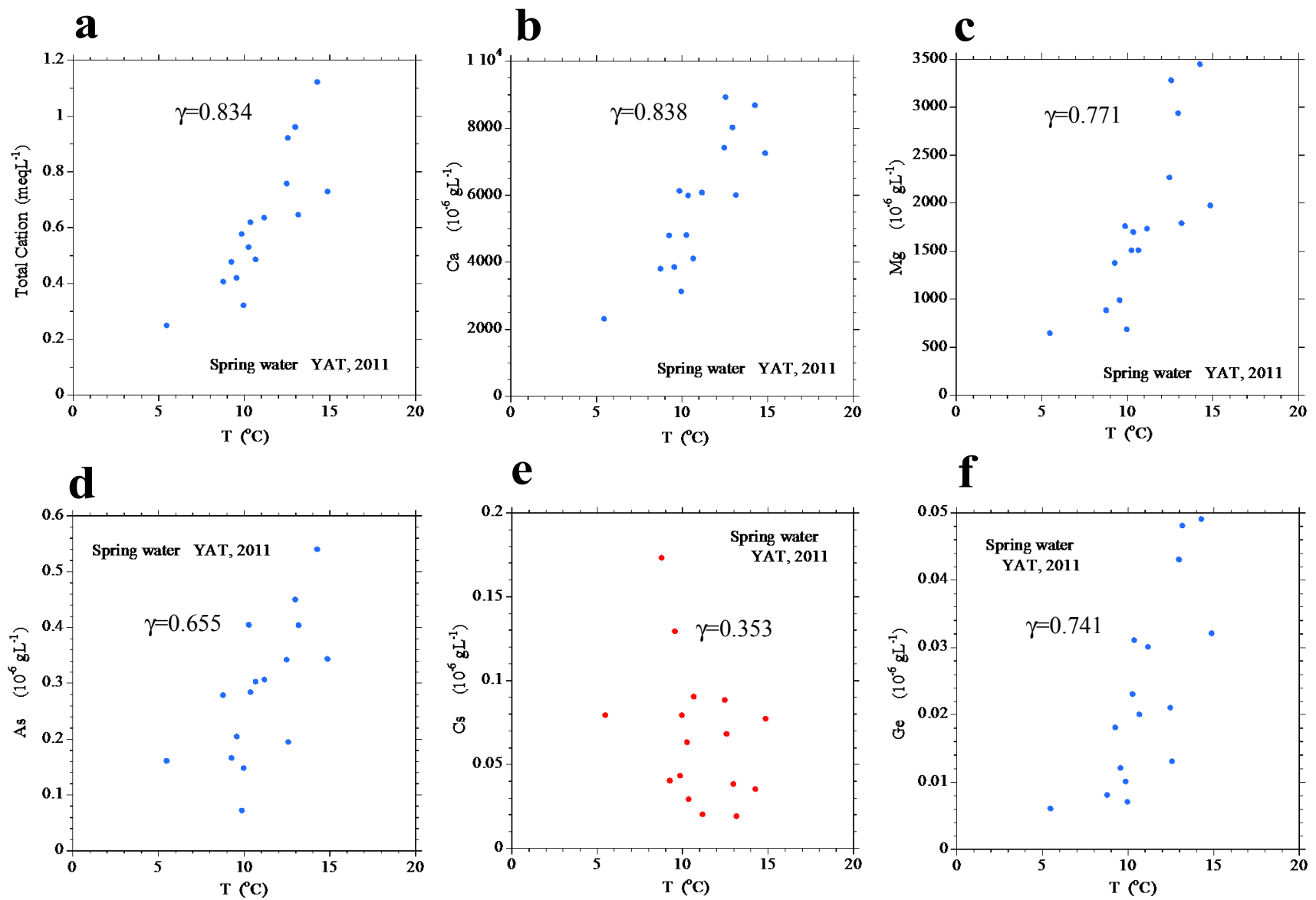

Fig. 6 - Relationship between concentration of dissolved elements and water temperature in spring water samples. a, Total cation; b, Ca; c, Mg; d, As; e, Cs; f, Ge. $\gamma$ indicates correlation coeffient. 
a
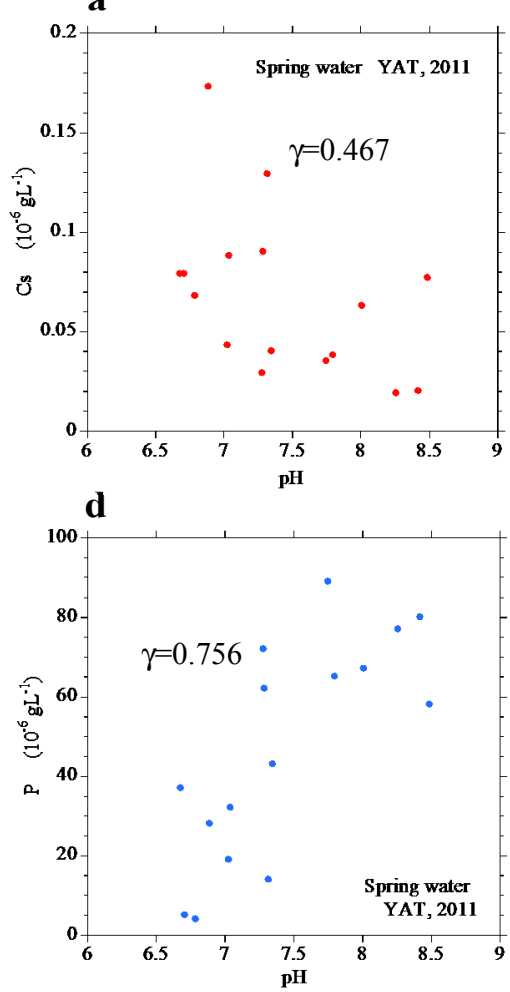
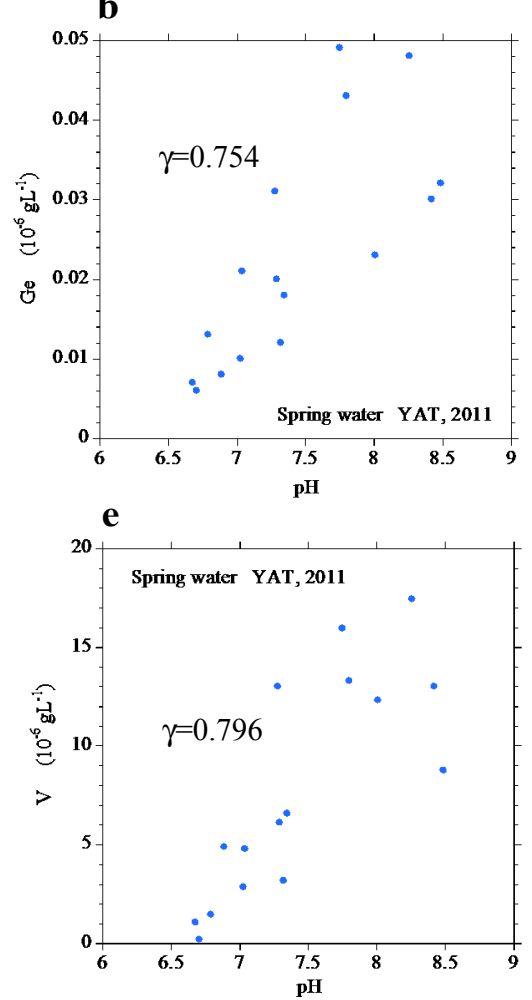
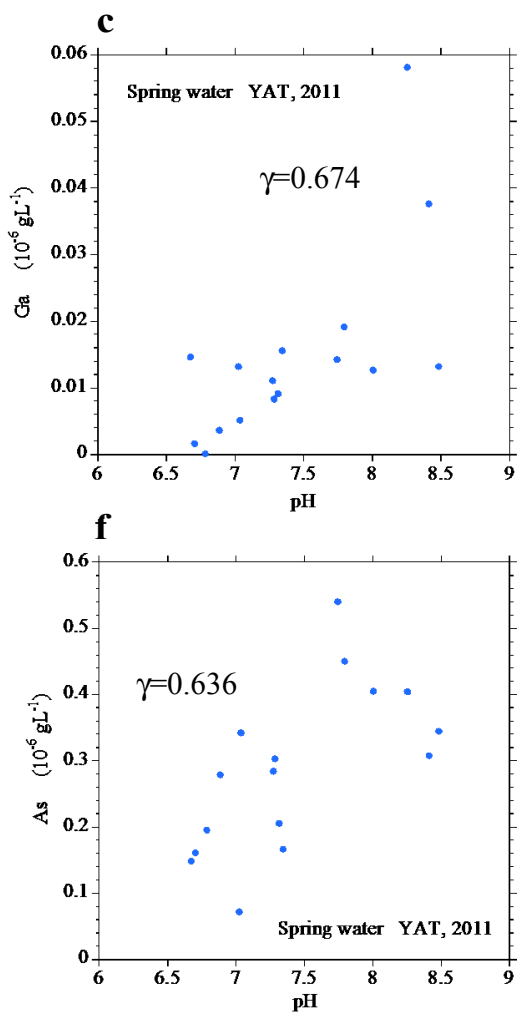

Fig. 7 - Relationship between concentration of dissolved trace elements and $\mathrm{pH}$ in spring water samples. a, Cs; b, Ge; c, Ga; d, P; e, V; f, As. $\gamma$ indicates correlation coeffient. 